\title{
COMMENT
}

\section{The long and the short of it}

\author{
Gregory A Petsko*
}

A smart investor who is a friend of mine used to evaluate biotechnology companies in an unusual way. Instead of looking at the balance sheet, or the list of scientific founders, or the technology platform, he looked at the parking lot. He would drive over to the company's research site on Wednesday and estimate the number of cars. Then he would come back on Sunday and count them again. If more than $70 \%$ of the employees were there working on Sunday, he would consider the company a likely candidate for investment. His reasoning was simple: if most of the employees were enthusiastic enough about what they were doing to spend their weekends doing it, the company probably had a future.

What I've always liked about this strategy (which was pretty successful, by the way) is that it placed more emphasis on human psychology than it did on statistics or analysts' reports. But he didn't carry it out as far as he could have: if he really believed in the predictive value of his method, I always argued, he should have taken out a short position on the companies that didn't meet his criterion as well as a long position on those that did.

By 'short' and 'long' I am referring to a common jargon used in the financial industry. A long position in a security, such as a stock or a bond means the holder of the position owns the security and will profit if the price of the security goes up. This is the normal expectation most people have when they invest, and it's what my friend would do with companies that met his $70 \%$ benchmark.

In contrast, a short position (also known as shorting or going short) is the practice of selling securities that have been borrowed from a third party (usually a broker) with the intention of buying the identical assets back at a later date to return to the lender - the reverse of the normal trading practice. In this case, the holder of the security is betting that its value will go down between the time of the sale of the borrowed stock and its repurchase later. If the value does drop as expected, the seller will pay less to buy the assets than the seller received on selling them, and will therefore make a profit. Of course, the short seller will incur a loss if the price of the assets rises.

*Correspondence: petsko@brandeis.edu

Rosenstiel Basic Medical Sciences Research Center, Brandeis University, Waltham, MA 02454-9110, USA
Here's an example of how this works: if shares in BioMed Central currently trade at $\$ 10$ per share, a short seller can borrow 100 shares of BioMed Central from a broker and immediately sell them for a total of $\$ 1,000$. If the price of the shares drops to $\$ 8$ per share, the short seller can then buy 100 shares back for $\$ 800$, return the shares to the broker and keep the $\$ 200$ profit (minus any borrowing fees).

Before you all rush out to take a short position on, say, US dollars (and I wouldn't blame you if you did, given how the dollar is doing these days), consider the following alternative scenario: if the price of the shares in BioMed Central instead rises to $\$ 20$ per share following the short sale, when the short seller is required to return to the broker the shares he/she borrowed, the short seller would have to buy back 100 shares at $\$ 2,000$ and would incur a loss of $\$ 1,000$ plus any borrowing fees. Note that this is completely opposite from the type of risk a holder of a long position would be in. If you're long on a stock, you can make a theoretically unlimited profit if the stock goes up, but your potential loss is limited to what you paid for it in the first place (since it can't go below zero in value). If you're short, your maximum profit is limited to the value of the security, but the theoretical loss is unlimited. Short sellers need to have the nerves of a Mississippi riverboat gambler.

So what I was arguing is that my friend ought to have gone short on companies whose employees didn't work on weekends as well as going long on those where they did. His counterargument, which makes sense (I said he was smart), was that a company that is going nowhere often has that reflected in its stock price, for example, the stock is liable to not move at all, in either direction, for long periods of time. Given that a short position requires borrowing stock temporarily, it was, he felt, too risky to bet on a biotech stock going down unless there was good reason to expect bad news about it.

It occurs to me that the long and short position jargon is very useful shorthand for talking about a lot of things, including the current state of science in general and genomics in particular. So here are my recommended positions on a variety of topics: I am advising that you go long on anything I think is undervalued or is likely to grow in value during the coming year, and to take a short position on anything I think is past its prime or that I expect to decline in worth. 


\section{Biotech companies}

Go long on any company that gets rid of its Scientific Advisory Board (SAB), and the earlier in its history that it does so, the better its prospects are. Companies have an $\mathrm{SAB}$ to tell them what they ought to be doing. Once they know, they don't need one anymore. Management that ditches its SAB is confident management with a good plan for the future. Any company that still has an SAB after five years or so is a company that has yet to find its way.

Go short on any company that keeps changing management. Stable, confident management is essential to any company's success. There's nothing wrong with making a change when you outgrow your founding management or when that management hasn't delivered, but if you have to keep doing it, something is not right. In fact, here's a good rule of thumb: if you have to choose between good technology and good management, pick management every time. Ideally, of course, you'd like to have both, but good management will find a way to acquire the technology it needs, while good technology with bad management will never go anywhere.

\section{Large pharmaceutical companies}

Go long on any company that has resisted the mergermania that has infected the industry. Giant pharmaceutical companies need an impossible number of blockbusters just to service their debt or generate enough return on capital to justify the merger, tend to stifle innovation rather than promote it, and are usually so bloated and complex that they are unmanageable. When it comes to making drugs, three smaller companies will almost always deliver more products than one company three times their size.

Go short on any big pharma company that reorganizes, especially if it has already done so in the recent past. Reorganization is what management does when it has no better ideas.

\section{Journals}

Go long on any journal that is attempting to fight the hegemony of the Impact Factor. There's a chance such a journal may actually care about the quality of the stuff it publishes.

Go short on journals that multiply like weeds, producing ever more specialized semi-clones of themselves. Not only are they diluting the brand; they are also likely to suffer a loss of quality. There simply aren't that many good editors and good referees in the world.

\section{Research trends}

Go long, for now, on anything that could be considered 'translational'. At least for the next few years, that's going to be the buzzword. There are several reasons for that. One is that a cabal of powerful and egotistical scientists oversold our ability to deliver cures for diseases so that they could get their pet big science projects funded. Another is that funding agencies are increasingly being run by people who believe they can, and should, set the direction of scientific research from the top down. If you can figure out how to package what you do in terms of translating basic discoveries to having an impact on some human disease, you should do well, for a while at least.

Go short in the long run (I know that sounds funny) on anything that could be considered 'translational. Making drugs is not a job for amateurs, and the funding agencies are very amateurish at it. Also, sooner or later, someone is going to realize that nobody has the foggiest idea how to accelerate the discovery of cures. Finally, if you think about it, all this new emphasis on 'translational research' is just repeating the same mistake: the powers that be are raising people's expectations again, and there is no chance, in my view, that they will be able to deliver in a time-frame that will satisfy those expectations.

\section{Genomics}

Go long on specific studies aimed at validating hypotheses or generating data that will lead to important hypotheses. That is called science.

Go short on studies that are just data gathering without any intelligence behind them. That is, as Rutherford said, called stamp collecting. My favorite example is the Genome Wide Association effort, which is tantamount to fishing in a dry lake.

\section{Teaching}

Go long on small class sizes, lots of required courses, and teachers who are really excited about their subject and the opportunity to teach it.

Go short on educational fads and the use of technology to replace the human interaction of student with teacher. Go really short on the idea that students should have a big say in what is taught and what they are required to learn. If that idea doesn't have the brief life-span it deserves, the future will be bleak indeed.

\section{Commentaries}

Go long on anything written by dogs, especially a pair named Mink and Clifford. They are to opinion pieces what Mozart was to sonatas.

Go short on anything written by people, especially people who write such things for a living. If they really knew anything, they would be making lots of money on what they knew. They wouldn't be wasting their time telling you what to go long and short on.

Published: 23 December 2010

doi:10.1186/gb-2010-11-12-145

Cite this article as: Petsko GA: The long and the short of it. Genome Biology 2010, 11:145. 